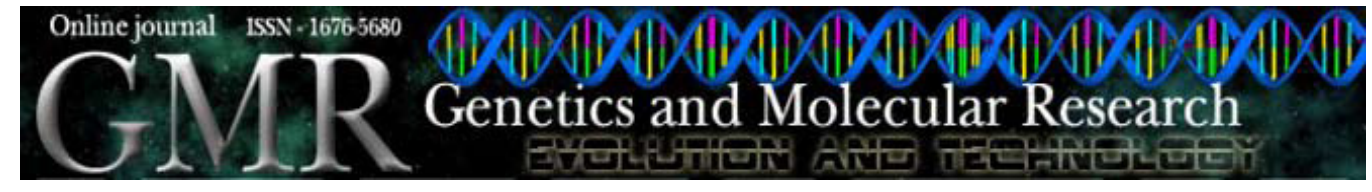

\title{
Mitotic crossing-over induced by two commercial herbicides in diploid strains of the fungus Aspergillus nidulans
}

\author{
R.A. Cardoso ${ }^{1}$, L.T.A. Pires ${ }^{2}$, T.D. Zucchi ${ }^{3}$, F.D. Zucchi ${ }^{4}$ and T.M.A.D. Zucchi ${ }^{4}$ \\ ${ }^{1}$ Centro Universitário do Triângulo, Uberlândia, MG, Brasil \\ ${ }^{2}$ Centro Universitário Moura Lacerda, Ribeirão Preto, SP, Brasil \\ ${ }^{3}$ Departamento de Entomologia e Acarologia, ESALQ, \\ Universidade de São Paulo, Piracicaba, SP, Brasil \\ ${ }^{4}$ Departamento de Parasitologia, Instituto de Ciências Biomédicas e \\ Centro de Pesquisas em Biotecnologia, \\ Universidade de São Paulo, São Paulo, SP, Brasil \\ Corresponding author: T.M.A.D. Zucchi \\ E-mail: tzucchi@uol.com.br
}

Genet. Mol. Res. 9 (1): 231-238 (2010)

Received October 7, 2009

Accepted December 13, 2009

Published February 9, 2010

\begin{abstract}
Some herbicides are suspected of promoting teratogenic, carcinogenic and mutagenic events. Detection of induced mitotic crossing-over has proven to be an indirect way of testing the carcinogenic properties of suspicious substances, because mitotic crossing-over is involved in the multistep process of carcinogenesis. We examined mitotic crossing-over induced by two commercial herbicides (diuron and trifluralin) in diploid strains of Aspergillus nidulans based on the homozygotization index. Low doses $(2.5 \mu \mathrm{g} / \mathrm{mL})$ of diuron were sufficient to increase the mean homozygotization index in 2.1 and 11.3 times for UT448// UT196 and $D p$ II-I//UT196, respectively, whereas the same dose of trifluralin increased this mean only 1.2 (UT448//UT196) and 3.5 (Dp II-I// UT196) times, respectively. The lower homozygotization index value found for trifluralin could be due to its interference with mitotic crossingover in eukaryotic cells. We concluded that the diploid $D p$ II-I//UT196 of A. nidulans is more sensitive to organic compounds than UT448//UT196;
\end{abstract}


these compounds cause recombinational events at a greater frequency in the latter diploid. This system holds promise as an initial test for carcinogenicity of organic compounds, including herbicides.

Key words: Diuron; Trifluralin; Herbicides; Mitotic crossing-over; Aspergillus nidulans; Genotoxic agents

\section{INTRODUCTION}

Currently, due to an increase in the population worldwide, there has been an urge for increasing the productivity of crops and agricultural by-products. This yield increment has been obtained mainly by a massive use of pesticides to control the impacts of noxious insects, phytopathogens and weeds in agriculture. Pesticides are a multimillion dollar market corresponding to an estimated value of 25.6 million dollars per year, and herbicides constitute $45 \%$ of this amount (Dich et al., 1997). However, a series of deleterious effects on environment safety and human health have become apparent, where teratogenic, carcinogenic, and mutagenic effects have received special attention (Giacomazzi and Cochet, 2004; Nguyen-Ngoc et al., 2009). Chemical pollutants present genetic hazards to human beings of sufficient importance to warrant intensive cytogenetic study (Sousa et al., 2009). Because of these undesirable side effects of pesticides, there has been an increase in consumer awareness to avoid the use of these compounds (Zucchi et al., 2008) and/or public pressure to enhance their regulation for applications in pre- or post-harvest.

Among the pesticides used, herbicides play a crucial role in agricultural fields to avoid crop competition by weeds. Diuron [1-(3, 4-dichlorophenyl)-3, 3-dimethylurea] is a pre-emergence urea herbicide (Van Boven et al., 1990) commonly used for the control of annual and perennial grasses in a number of crops (Hardaway and Yalkowsky, 1991). It is poorly soluble in water, which leads to its accumulation in animal tissues, and therefore, diuron toxicity has been well established (Singh and Bingley, 1990). The oral $\mathrm{LD}_{50}$ value of diuron for rats is over $3 \mathrm{~g} / \mathrm{kg}$ (Dikshith, 1990), and it has been considered moderately toxic (Hardaway and Yalkowsky, 1991). Also, it has been usually classified as highly persistent in environmental conditions, and therefore, diuron can be found in soil, sediments and water (Field et al., 2003). Trifluralin [2,6-dinitro-N, N-dipropyl-4(trifluoromethyl) benzenamine] is a pre-emergence soil-incorporated herbicide and one of the most widely used herbicides in weed control (Deuber, 1992). Even though it has been proven to be slightly toxic to mammals (Garriott et al., 1991), several reports have demonstrated that trifluralin has genotoxic properties (Könen and Çavas, 2008; Fernandes et al., 2009). Although many reports have highlighted the genotoxic properties of both herbicides by several biosafety assays, to the best of our knowledge, none of them evaluated the potential of diuron and trifluralin to provoke recombinational alterations by homozygotization of Aspergillus nidulans.

The homozygotization index (HI) (Pires and Zucchi, 1994) is based on two or more $A$. nidulans diploid strains heterozygous for several well-mapped genetic markers. The homozygotization of these heterozygous markers has proven to be sensitive enough to detect recombinational alterations induced by noxious agents (Zucchi et al., 2005). Mitotic recombination is a natural tool for DNA repair, which plays an intricate association with loss of heterozygosity (Young et al., 2006), and therefore, it was demonstrated to be linked to carcinogenesis as a prior step in this process (Gupta et al., 1997). Hence, it is a highly desirable focus in efforts to 
enhance our knowledge of the recombinogenic potential of suspicious compounds. Thus, the main aim of this study was to evaluate the recombinogenic effect of diuron and trifluralin on the homozygotization of genes of $A$. nidulans diploid strains.

\section{MATERIAL AND METHODS}

\section{Aspergillus nidulans strains}

The haploid strains used were from Utrecht stocks (UT448 and UT196) or obtained in our laboratory, namely $D p$ II-I, which is a uvs mutant obtained from N-methyl-N'-nitroNnitrosoguanidine treatment of the UT448 strain (Zucchi, 1990; Prado and Zucchi, 1991a,b; Castro-Prado and Zucchi, 1992). Their genotypes are given in Table 1.

\section{Table 1. Genotypes and linkage group of Aspergillus nidulans strains.}

\begin{tabular}{ll}
\hline Strain & \multicolumn{1}{c}{ Genotype } \\
\hline UT448 & riboA1 (I), pabaA124 (I), biA1 (I), AcrA1 (II), wA2 (II) \\
UT196 & $y \mathrm{~A} 2$ (I), methA17 (II), pyroA4 (IV) \\
$D p$ II-I & $w \mathrm{~A} 2$ (II), riboA1 (I), pabaA124 (I), $p p$ II-I (I), biA1 (I), uvsA (I), AcrA1 (II) \\
\hline
\end{tabular}

riboA 1 = riboflavin; pabaA124 = p-aminobenzoic acid; biA1 = biotin; meth $\mathrm{A} 17=$ methionine; pyroA $4=$ pyridoxine; Conidia color: $w \mathrm{~A} 2=$ white; $y \mathrm{~A} 2=$ yellow; $A c r \mathrm{~A} 1=$ resistance to acriflavine; $u v s \mathrm{~A}=$ sensitivity to UV; $D p$ II-I $=$ duplication of a segment of chromosome II transposed to chromosome I, inserted into paba-y interval.

The diploid strains UT448//UT196, $D p$ II-I//UT196 and UT501//UT196 were prepared according to Roper's method (1952). The mutant alleles were allocated to their linkage group by mitotic haploidization (Forbes, 1959) facilitated by treatment with $p$-fluorophenylalanine ( $p$ FA) (Lhoas, 1961; Morpurgo, 1961).

\section{Culture media}

Complete medium (CM) and minimal medium (MM) were prepared as described by Van de Vate and Jansen (1978). Selective medium (SM) was MM supplemented with requirements needed by the particular strains. Solid medium contained $1.5 \%$ agar. Incubation was at $37^{\circ} \mathrm{C}$.

\section{Solutions}

The herbicide solutions contained $2 \mathrm{mg} / \mathrm{mL}$ of the active ingredient in distilled water. Diuron was obtained from Hoechst and trifluralin from Elanco. The haploidizing agent $p \mathrm{FA}$ was diluted in $0.1 \mathrm{~N} \mathrm{NaOH}(20 \mathrm{mg} / \mathrm{mL})$.

\section{Procedures}

The herbicide solutions were individually and directly added to solid $\mathrm{MM}$ at $45^{\circ} \mathrm{C}$ at different final concentrations $(0,0.25,2.5,25.0$, and $250.0 \mu \mathrm{g} / \mathrm{mL})$. Conidia from each of the diploid strains were added to the center of these plates. After incubation for $5-7$ days at $37^{\circ} \mathrm{C}$, it was 
possible to determine green sectors growing in colonies of treated diploids, which were probably recombinant diploids. Such diploid sectors were individually isolated on $\mathrm{MM}$ and then transferred to 4 points of $10 \mathrm{CM}$ plates amended with $p \mathrm{FA}(0.035 \mathrm{mg} / \mathrm{mL})$ to be haploidized. The plates were then incubated for 3-5 days until colored haploid sectors appeared. In order to determine their genotypes, conidia from the edge of these haploid sectors were transferred to 25 defined positions ( 5 x 5 pattern) of CM plates and incubated for $48 \mathrm{~h}$, and they were then replicated to SM (MM plus $1 \mu \mathrm{g} / \mathrm{mL}$ riboflavin, $0.7 \mu \mathrm{g} / \mathrm{mL} p$-aminobenzoic acid, $0.02 \mu \mathrm{g} / \mathrm{mL}$ biotin, $0.5 \mu \mathrm{g} / \mathrm{mL}$ methionine), SM lacking individually riboflavin, $p$-aminobenzoic acid, biotin and methionine, and SM plus acriflavine $(62 \mu \mathrm{g} / \mathrm{mL})$. After a 48 -h incubation at $37^{\circ} \mathrm{C}$, the genotypes of the haploid segregants were determined, and the frequency of mitotic crossing-over was then evaluated.

\section{Homozygotization index evaluation}

The frequency of mitotic crossing-over was determined by calculating the HI, which was according to Pires and Zucchi (1994) and briefly reviewed by Stoll et al. (2008).

\section{RESULTS}

For each herbicide treatment of the original diploid strains (UT448//UT196 and $D p$ III/UT196) prior to HI evaluation, these diploids were haploidized. Diuron treatment increased the HI values for both diploids. The most substantial results were found in treatment with a concentration of $2.5 \mu \mathrm{g} / \mathrm{mL}$. Diploid UT448//UT196 showed an increase in HI values for ribo, $p a b a$ and $b i$ markers (Table 2A, Figure 1A), while in diploid $D p$ II-I//UT196, the effect of herbicide treatment was noticed scattered all over the markers analyzed (Table 2B, Figure 1B). The markers AcrR and meth, from the UT448//UT196 diploid, showed similar HI in the control group after treatments with concentrations of $0.25,2.5$ and $25 \mu \mathrm{g} / \mathrm{mL}$ and decreased at higher concentrations ( 75.0 and $250.0 \mu \mathrm{g} / \mathrm{mL}$ ). In fact, a similar pattern was found for $D p$ II-I diploid, where HI for these markers (AcrR and meth) was smaller at the highest dose $(250.0 \mu \mathrm{g} / \mathrm{mL})$.

\begin{tabular}{|c|c|c|c|c|c|}
\hline \multicolumn{6}{|l|}{ A. } \\
\hline \multirow[t]{2}{*}{ Dose $(\mu \mathrm{g} / \mathrm{mL})$} & \multicolumn{5}{|c|}{ HI UT448//UT196 (genetic markers) } \\
\hline & ribo & paba & $b i$ & AcrR & meth \\
\hline Control & 1.50 & 2.33 & 2.33 & 9.00 & 9.00 \\
\hline 0.25 & 7.00 & 7.00 & 7.00 & 8.00 & 8.00 \\
\hline 2.5 & 10.00 & 10.00 & 10.00 & 11.00 & 11.00 \\
\hline 25.0 & 2.00 & 2.00 & 2.00 & 12.00 & 12.00 \\
\hline 75.0 & 3.00 & 3.00 & 3.00 & 5.00 & 5.00 \\
\hline 250.0 & 3.00 & 3.00 & 3.00 & 2.33 & 2.33 \\
\hline \multicolumn{6}{|l|}{ B. } \\
\hline \multirow[t]{2}{*}{ Dose $(\mu \mathrm{g} / \mathrm{mL})$} & \multicolumn{5}{|c|}{ HI $D p$ II-I//UT196 (genetic markers) } \\
\hline & ribo & paba & $b i$ & AcrR & meth \\
\hline Control & 1.00 & 1.22 & 1.22 & 3.00 & 5.67 \\
\hline 0.25 & 6.00 & 9.50 & 9.50 & 6.00 & 6.00 \\
\hline 2.5 & 31.00 & 31.00 & 9.67 & 32.00 & 32.00 \\
\hline 25.0 & 3.40 & 3.40 & 4.50 & 2.67 & 3.40 \\
\hline 75.0 & 4.38 & 4.38 & 2.91 & 9.75 & 5.14 \\
\hline 250.0 & 6.75 & 5.20 & 4.17 & 1.38 & 2.44 \\
\hline
\end{tabular}




\section{A $\quad$ UT448IIUT196}

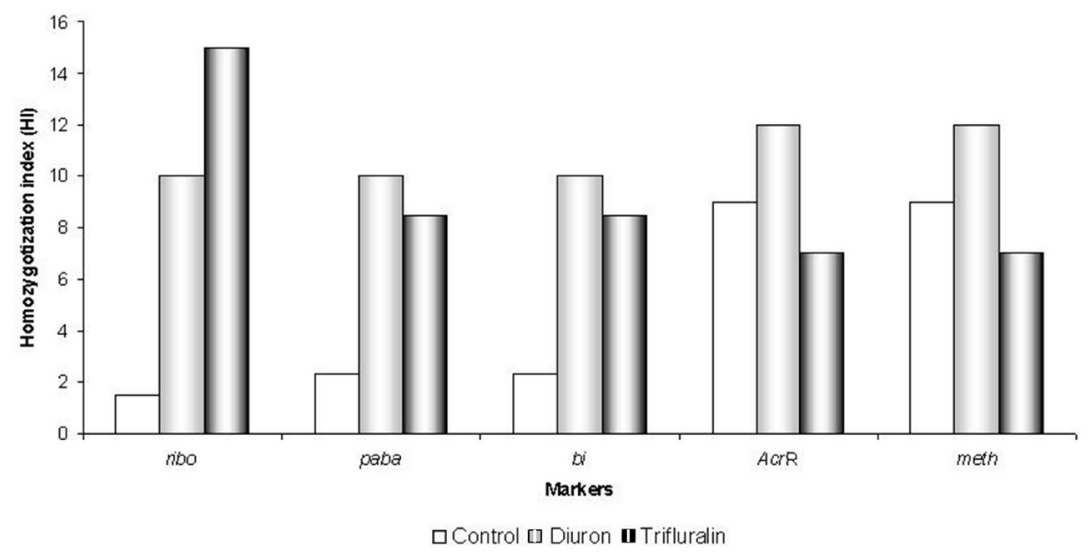

B Dp II-IIUT196

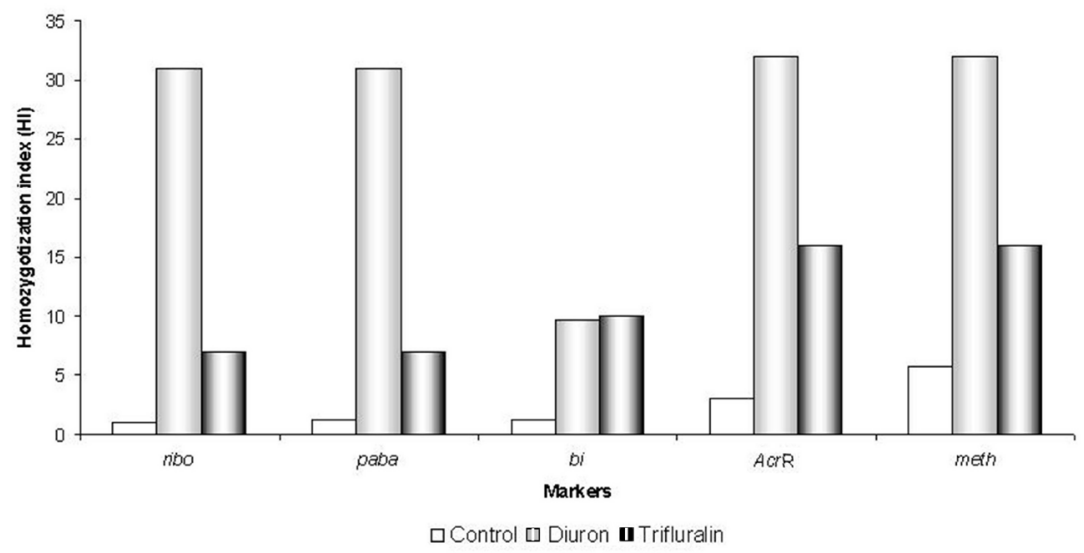

Figure 1. Maximum homozygotization index found after herbicide treatment.

In general, HI for all markers increased after trifluralin treatment. In the diploid UT448//UT196, trifluralin treatment at a concentration of $2.5 \mu \mathrm{g} / \mathrm{mL}$ was also able to induce the highest recombination rates for $p a b a$ and $b i$ markers. However, the highest HI for ribo marker was found at a concentration of $25.0 \mu \mathrm{g} / \mathrm{mL}$ (Table 3A, Figure 1A). Similar to those results obtained for diuron treatment of UT448//UT196 diploid, AcrR and meth showed a recombination rate smaller than that observed in control. In fact, AcrR and meth markers had HI higher than expected for control experiments of this diploid. Unfortunately, a general explanation for this observation is presently not possible on account of the limitations of the present experiments. The segregation rates found for $D p$ II-I//UT196 diploid treated with trifluralin were, in general, smaller than those found for diuron treatment. Also, a higher concentration was necessary to obtain the highest HI for ribo, paba and bi markers (Table 3B, Figure 1B). AcrR and meth showed the same pattern found for diuron treatment. 
Table 3. Homozygotization index (HI) of UT448//UT196 (A) and Dp II-I//UT196 (B) diploid strains under trifluralin treatments.

\begin{tabular}{|c|c|c|c|c|c|}
\hline \multicolumn{6}{|l|}{ A. } \\
\hline \multirow[t]{2}{*}{ Dose $(\mu \mathrm{g} / \mathrm{mL})$} & \multicolumn{5}{|c|}{ HI UT448//UT196 (genetic markers) } \\
\hline & ribo & $p a b a$ & $b i$ & Acr R & meth \\
\hline Control & 1.50 & 2.33 & 2.33 & 9.00 & 9.00 \\
\hline 0.25 & 1.29 & 1.00 & 1.29 & 7.00 & 7.00 \\
\hline 2.5 & 8.50 & 8.50 & 8.50 & 1.71 & 1.71 \\
\hline 25.0 & 15.00 & 3.00 & 3.00 & 7.00 & 7.00 \\
\hline 75.0 & 3.25 & 3.25 & 3.25 & 3.25 & 3.25 \\
\hline 250.0 & 3.67 & 3.67 & 3.67 & 3.67 & 3.67 \\
\hline \multicolumn{6}{|l|}{ B. } \\
\hline \multirow[t]{2}{*}{ Dose $(\mu \mathrm{g} / \mathrm{mL})$} & \multicolumn{5}{|c|}{ HI $D p$ II-I//UT196 (genetic markers) } \\
\hline & ribo & $p a b a$ & $b i$ & AcrR & meth \\
\hline Control & 1.00 & 1.20 & 1.20 & 3.00 & 5.67 \\
\hline 0.25 & 7.00 & 7.00 & 4.33 & 15.00 & 7.00 \\
\hline 2.5 & 3.25 & 3.25 & 3.25 & 16.00 & 16.00 \\
\hline 25.0 & 2.50 & 2.50 & 3.67 & 13.00 & 13.00 \\
\hline 75.0 & 2.67 & 4.50 & 10.00 & 10.00 & 10.00 \\
\hline 250.0 & 7.50 & 7.50 & 4.67 & 3.25 & 2.40 \\
\hline
\end{tabular}

Therefore, as homozygotes for conidial color marker are not selected in MM (any color conidia survive on MM, which did not lead to a segregation rate distortion), these markers were not included in this analysis.

Based on the results presented herein, two gene sets can be distinguished according to their patterns. The first one involves the ribo, paba and $b i$ markers, which showed very similar HIs in the two diploid strains. This suggests that they segregate together, without mitotic crossing-over events between them. The other involves the AcrR and meth markers of chromosome II. Even though the herbicide concentration needed to induce the highest segregation rates for both diploids was usually the same $(2.5 \mu \mathrm{g} / \mathrm{mL})$, the values found for $D p$ II-I//UT196 were higher for all markers analyzed. This finding demonstrates the sensitivity of this diploid for recombinogenic analysis.

\section{DISCUSSION}

Indiscriminate use of pesticides has been described as being responsible for causing several hazardous problems with regard to the environment and human health (Pingali and Gerpacio, 1998). Diuron and trifluralin became two of the most used herbicides worldwide, and often have been associated with poisoning and environmental contamination (McMahon et al., 2005; Fernandes et al., 2009). Nevertheless, many studies have demonstrated genotoxic properties for both herbicides (Ebert et al., 1992; Giacomazi and Cochet, 2004), and therefore, some countries banned their use (Konstantinou and Albanis, 2004; Könen and Çavas, 2008). Although both herbicides have shown noxious effects after being evaluated by many biosafety assays, some of these tests did not demonstrate any genotoxic hazards to human beings (Garriott et al., 1991). These singular discrepancies have been explained by non-applicability between the tested-compound and bioassay methods used (Uhl et al., 2003), and therefore, this suggests the importance of analyzing the suspicious substances in several biological systems.

The use of heterozygous diploids of $A$. nidulans has proven to be a feasible alternative to evaluate induced genetic events after treatment with some hazardous agents (Sousa et 
al., 2009). By this assay, both herbicides were able to induce mitotic crossing-over in diploid strains of $A$. nidulans and the most substantial results were obtained in $D p$ II-I//UT196 diploid strain after diuron treatment. The HI has already been applied to evaluate the genotoxicity of organic compounds, and the findings presented herein corroborate the previously described sensitivity to detect such events (Salvador et al., 2008).

In general, the maximum HI value found for UT448//UT196 and $D p$ II-I//UT196 diploid strains was obtained at a concentration of $2.5 \mu \mathrm{g} / \mathrm{mL}$, for both herbicides. Interestingly, this concentration has been commonly reported in soil contaminated with diuron and trifluralin (Moorman and Koskinen, 1990; Garriott et al., 1991). In treatments with higher herbicide concentration there was a decrease in HI values. This pattern is in line with findings by Kunz et al. (1985) who demonstrated that higher doses of genotoxic agents did not correspond to higher recombination rates. Probably, the highest doses of diuron and trifluralin caused more cytotoxic effects (e.g., cell death) than recombinogenic events.

Even though trifluralin treatment was shown to be recombinogenic in A. nidulans cells, the HI values found were lower than that of the other herbicide. Hence, this observed pattern could have been influenced by trifluralin's ability to inhibit mitotic cell division (Fernandes et al., 2007, 2009). In fact, compounds known to be anti-carcinogenic, such as isoflavanoids from soybeans, could interfere in the homozygotization process preventing homozygote formation, which leads to elevated HI values (Zucchi, 2006). Accordingly, due to the well-known genotoxic nature of trifluralin and the HI values obtained, the discrepancies between the two herbicides were basically due to their recombinogenic property, and their mitotic inhibition pattern apparently did not interfere with the results.

As demonstrated herein, a bioassay focusing on mitotic recombination of $A$. nidulans was efficient in detecting the genotoxic effects of diuron and trifluralin. As mitotic crossingover has been related to carcinogenesis in higher eukaryotic cells (Gupta et al., 1997), the HI test proved to be a powerful tool to evaluate suspicious recombinogenic pesticides and should be taken into consideration in further toxicology studies of herbicides.

\section{ACKNOWLEDGMENTS}

Research supported by FAPESP (Fundação de Amparo à Pesquisa do Estado de São Paulo, Proc. \#90/0227-1, Brazil) and CNPq (Conselho Nacional de Desenvolvimento Científico e Tecnológico, Proc. \#50007590-5, Brazil). The authors are grateful to Mrs. Boel M.M. Sandskar for suggestions and revision of the manuscript, to Mrs. Sônia Mathias da Silva for technical assistance, and to Mrs. Célia Luisa Reily Rocha for revision of the manuscript.

\section{REFERENCES}

Castro-Prado MAAC and Zucchi TMAD (1992). Characterization of the Dp (II-I) duplication in A. nidulans: presence of the Acr A1 gene and its regulatory transcription sequence in the transposed segment. Braz. J. Genet. 15: 777-788.

Deuber R (1992). Botânica das Plantas Daninhas. In: Ciência das Plantas Daninhas (Deuber R, ed.). FUNEP, Jaboticabal, 31-73. Dich J, Zahm SH, Hanberg A and Adami HO (1997). Pesticides and cancer. Cancer Causes Control 8: 420-443.

Dikshith TSS (1990). Pesticides. In: Toxicology of Pesticides in Animals (Dikshith TSS, ed.). CRC Press, Boca Raton, 1-40.

Ebert E, Leist KH, Hack R and Ehling G (1992). Toxicology and hazard potential of trifluralin. Food Chem. Toxicol. 30 : 1031-1044.

Fernandes TCC, Mazzeo DEC and Martin-Morales MA (2007). Mechanism of micronuclei formation in polyploidizated cells of Allium cepa exposed to trifluralin herbicide. Pesticide Biochem. Physiol. 88: 252-259.

Fernandes TC, Mazzeo DE and Marin-Morales MA (2009). Origin of nuclear and chromosomal alterations derived from 
the action of an aneugenic agent - Trifluralin herbicide. Ecotoxicol. Environ. Saf. 72: 1680-1686.

Field JA, Reed RL, Sawyer TE, Griffith SM, et al. (2003). Diuron occurrence and distribution in soil and surface and ground water associated with grass seed production. J. Environ. Qual. 32: 171-179.

Forbes E (1959). Use of mitotic segregation for assigning genes to linkage groups in Aspergillus nidulans. Heredity 13: 67-80.

Garriott ML, Adams ER, Probst GS, Emmerson JL, et al. (1991). Genotoxicity studies on the preemergence herbicide trifluralin. Mutat. Res. 260: 187-193.

Giacomazzi S and Cochet N (2004). Environmental impact of diuron transformation: a review. Chemosphere 56: 1021-1032.

Gupta PK, Sahota A, Boyadjiev SA, Bye S, et al. (1997). High frequency in vivo loss of heterozygosity is primarily a consequence of mitotic recombination. Cancer Res. 57: 1188-1193.

Hardaway LA and Yalkowsky SH (1991). Cosolvent effects on diuron solubility. J. Pharm. Sci. 80: 197-198.

Konstantinou IK and Albanis TA (2004). Worldwide occurrence and effects of antifouling paint booster biocides in the aquatic environment: a review. Environ. Int. 30: 235-248.

Könen S and Çavas T (2008). Genotoxicity testing of the herbicide trifluralin and its commercial formulation Treflan using the piscine micronucleus test. Environ. Mol. Mutagen. 49: 434-438.

Kunz BA, Eckardt F and Haynes RH (1985). Analysis of non-linearities in frequency curves for UV-induced mitotic recombination in wild-type and excision-repair-deficient strains of yeast. Mutat. Res. 151: 235-242.

Lhoas P (1961). Mitotic haploidization by treatment of Aspergillus niger diploids with para-fluorophenylalanine. Nature 190: 744.

McMahon K, Bengtson NS, Eaglesham G, Muller JF, et al. (2005). Herbicide contamination and the potential impact to seagrass meadows in Hervey Bay, Queensland, Australia. Mar. Pollut. Bull. 51: 325-334.

Moorman TB and Koskinen WC (1990). Effects of diuron and fluometuron metabolites on the growth and fiber quality of cotton (Gossypium hirsutum). Bull. Environ. Contam. Toxicol. 44: 260-267.

Morpurgo G (1961). Somatic segregation induced by p-fluorophenylatanine. Aspergillus Newsl. 2: 10.

Nguyen-Ngoc H, Durrieu C and Tran-Minh C (2009). Synchronous-scan fluorescence of algal cells for toxicity assessment of heavy metals and herbicides. Ecotoxicol. Environ. Saf. 72: 316-320.

Pingali PL and Gerpacio RV (1998). Toward Reduced Pesticide Use for Cereal Crops in Asia. In: Agriculture and the Environment: Perspectives on Sustainable Rural Development (Lutz E, ed.). World Bank, Washington, 254-270.

Pires LTA and Zucchi TMAD (1994). A new method to detect potential genotoxic agents using mitotic crossing-over in diploid strains of A. nidulans. Rev. Bras. Genet. 17: 371-376.

Prado MAAC and Zucchi TMAD (1991a). Stabilization of a duplicated segment Dp (II-I) in an uvs mutant of Aspergillus nidulans through genetic mechanisms. Rev. Bras. Genet. 14: 239-248.

Prado MAAC and Zucchi TMAD (1991b). Meiotic segregation of a recessive gene (wA2) included in a Dp (II-I) of Aspergillus nidulans. Rev. Bras. Genet. 14: 249-260.

Roper JA (1952). Production of heterozygous diploids in filamentous fungi. Experientia 8: 14-15.

Salvador MJ, Zucchi TD, Schinor EC and Dias DA (2008). Genotoxic potentials of natural products detected by a shortterm test using diploid strains of Aspergillus nidulans. Open Mycol. J. 2: 48-54.

Singh J and Bingley R (1990). Levels of 3,3',4,4'-tetrachloroazobenzene in diuron and linuron herbicide formulations. $J$. Assoc. Off. Anal. Chem. 73: 749-751.

Sousa GD, Zucchi TD, Zucchi FD, Miller RG, et al. (2009). Aspergillus nidulans as a biological system to detect the genotoxic effects of mercury fumes on eukaryotes. Genet. Mol. Res. 8: 404-413.

Stoll LB, Cremonesi FC, Pires LT, Zucchi TD, et al. (2008). Induction of mitotic crossing-over in diploid strains of Aspergillus nidulans using low-dose X-rays. Genet. Mol. Res. 7: 467-475.

Uhl M, Plewa MJ, Majer BJ and Knasmüller S (2003). Basic Principles of Genetic Toxicology with an Emphasis on Plant Bioassays. In: Bioassays in Plant Cells for Improvement of Ecosystem and Human Health (Maluszynska J and Plewa M, eds.). Wydawnictvo Uniwersytetu Ślaskiego, Katowice, 11-30.

Van Boven M, Laruelle L and Daenens P (1990). HPLC analysis of diuron and metabolites in blood and urine. J. Anal. Toxicol. 14: 231-234.

Van de Vate C and Jansen GJ (1978). Meiotic recombination in a duplication strain of Aspergillus nidulans. Genet. Res. 31: $29-52$.

Young BD, Debernardi S, Lillington DM, Skoulakis S, et al. (2006). A role for mitotic recombination in leukemogenesis. Adv. Enzyme Regul. 46: 90-97.

Zucchi FD (2006). Linhagens de Aspergillus nidulans como biossensores de efeitos genotóxicos e antigenotóxicos de agentes ambientais. PhD. thesis, Biotechnology Interunities, Post-Graduation Program, São Paulo University, São Paulo.

Zucchi TD, Zucchi FD, Poli P, Melo IS, et al. (2005). A short-term test adapted to detect the genotoxic effects of environmental volatile pollutants (benzene fumes) using the filamentous fungus Aspergillus nidulans. J. Environ. Monit. 7: 598-602.

Zucchi TD, de Moraes LA and de Melo IS (2008). Streptomyces sp. ASBV-1 reduces aflatoxin accumulation by Aspergillus parasiticus in peanut grains. J. Appl. Microbiol. 105: 2153-2160.

Zucchi TMAD (1990). Isolation of putative recombination mutants of Aspergillus nidulans. Rev. Bras. Genet. 13: 409-424.

Genetics and Molecular Research 9 (1): 231-238 (2010)

CFUNPEC-RP www.funpecrp.com.br 